\title{
KINERJA KARYAWAN DITINJAU DARI ASPEK MOTIVASI DAN LINGKUNGAN KERJA
}

\author{
Norhayati \\ Fakultas Ekonomi dan Bisnis Islam, Universitas Islam Zainul Hasan \\ Genggong Probolinggo \\ Email: yatik.lmj15@gmail.com
}

\begin{abstract}
This study aims to determine and analyze the effect of motivation and compensation on employee performance in CV Sari Sofa Lumajang. The design of this research is explanatory research. The data analysis used is Multiple Linear Regression Analysis. The results of this research showed that motivation has a positive effect on employee performance. Compensation has a positive effect on employee performance.
\end{abstract}

Keywords: Motivation ; Compensation ; Employee Performance

\section{PENDAHULUAN}

Perkembangan teknologi yang pesat, tingkat pertumbuhan ekonomi yang tinggi dan perkembangan tingkat permintaan yang kompleks mengakibatkan timbulnya berbagai cabang industri yang hanya semata-mata menjawab kebutuhan masyarakat. Salah satu industri yang kini banyak meningkatkan sektor perekonomian adalah industri meubel. Industri meubel yang semakin bertambah sehingga membawa pengaruh menguatnya pasaran hasil meubel didalam negeri. Meubel Sari Sofa Lumajang merupakan salah satu perusahaan di Lumajang dengan tenaga kerja yang cukup besar dengan kegiatan usahanya 
yang membutuhkan ketrampilan dibidang pertukangan. Sari Sofa Lumajang melayani pemesanan sesuai dengan permintaan pemesan, dengan cara pemesan memberikan gambaran atau konsep barang yang akan dipesan.

Keberhasilan Sari Sofa Lumanjang berkaitan erat dengan peranan dari sumberdaya manusia atau karyawan. Jika karyawan dapat bekerja dengan kaulitas yang terbaik sesuai dengan permintaan konsumen maka tidak menutup kemungkinan Sari Sofa Lumajang menjadi produk yang go internasional. Upaya untuk meningkatkan penjualan produk menuntut pelaku usaha melakukan pengelolaan manajemen dengan baik, sehingga akan dapat

menguasai pangsa pasarnya. Suatu perusahaan akan dapat menguasai pangsa pasar yang luas apabila memiliki performance yang baik dalam arti luas termasuk dalam melakukan efisiensi sumber-sumber ekonomi yang dimiliki perusahaan agar tetap survive. Peranan sumber daya manusia dalam suatu organisasi sangatlah penting. Sumber daya manusia ini merupakan penggerak utama atas kelancaran jalannya organisasi. Sumber daya manusia adalah karyawan yang siap, mampu, dan siaga dalam mencapai tujuan-tujuan organisasi. $^{1}$ Setiap organisasi selalu menginginkan para karyawan untuk dapat bekerja dengan baik, karena hal ini akan berpengaruh terhadap kemajuan organisasi itu sendiri. Hal utama yang dituntut oleh organisasi dari karyawan adalah kinerja yang sesuai dengan standar yang telah ditetapkan oleh organisasi. Oleh karena itu diperlukan manajemen karyawan yang baik mencapai kinerja yang diharapkan.

1 Sutrisno, Edi. 2009. Manajemen Sumber Daya Manusia Edisi pertama. (Jakarta: Kencana Prenada Media Group), hlm. 1. 
Penilaian kinerja pada dasarnya merupakan faktor kunci guna mengembangkan suatu organisasi secara efektif dan efesien, karena adanya kebijakan atau program yang lebih baik atas sumber daya manusia yang ada dalam organisasi. Kinerja merupakan hasil kerja yang dihasilkan oleh karyawan atau perilaku nyata yang ditampilkan sesuai dengan perannya dalam organisasi. ${ }^{2}$ Peningkatan kinerja karyawan akan membawa kemajuan bagi perusahaan untuk dapat bertahan dalam suatu persaingan lingkungan bisnis yang tidak stabil. Sejauh ini kinerja karyawan sangat fluktuatif, hal ini ditandai dengan banyaknya pemesanaan konsumen yang tidak bisa dikerjakan dengan tepat waktu, pemesanan dikerjakan tidak sesuai dengan permintaan konsumen, jumlah produk yang dihasilakan semakin menurun, adanya komunikasi yang kurang baik sesama karyawan. Keadaan ini bukan tanpa sebab melainkan dipengaruhi oleh rendahnya motivasi kerja karyawan, minimnya kompensasi yang diberikan serta lingkungan yang kurang nyaman dalam bekerja.

Motivasi dikatakan sebagai salah satu faktor yang mempengaruhi kinerja karyawan. Setiap manajer dalam level apapun akan senantiasa dituntut untuk berbuat sesuatu yang dapat mempengaruhi orang-orang yang dipimpinnya termotivasi, sehingga anggota organisasi tersebut dapat memberikan kinerja yang memuaskan, karena mereka melakukan tugasnya dengan perasaan gembira, dalam suasana kegairahan yang tinggi, dan tidak tertekan. ${ }^{3}$ Motivasi dalam bekerja harus diperhatikan oleh perusahaan agar dapat mengetahui motif dan motivasi yang diinginkan

\footnotetext{
2 Hariandja, Marihot Tua Efendi. 2007. Manajemen Sumber Daya Manusia : Pengadaan, Pengembangan, Pengkompensasian, dan Peningkatan Produktivitas Pegawai. (Jakarta : Grasindo),hlm. 2

${ }^{3}$ Ardana , Komang dkk.2009. Perilaku Keorganisasian. (Yogyakarta: Graha Ilmu), hlm. 29.
} 
karyawan sehingga karyawan mempunyai semangat kerja dalam pencapaian tujuan perusahaan yang telah direncanakan dan pada akhirnya perusahaan memiliki karyawan yang mempunyai kemampuan, ketrampilan dan kecakapan dalam bekerja. Motivasi kerja karyawan Sari Sofa Lumajang digambarkan dengan beberapa keadaan seperti tidak maksimalnya jam kerja untuk kegiatan bekerja, seringnya menunda pekerjaan, lebih suka kerja lembur. Rendahnyanya motivasi kerja karyawan akan berdampak pada pencapaian kenerja perusahaan. Semakin baik motivasi yang dimiliki karyawan maka memungkinkan akan semakin baik kinerjanya. upaya untuk meningkatkan motivasi kerja yang baik dengan memberikan pengarahan kepada karyawan.

Pengembangan atau peningkatan kinerja karyawan dapat dilakukan dengan membayarkan kompensasi menurut kondisi pasar, aman, mengandung nilai-nilai kekeluargaan, dan mampu memenuhi kebutuhan keluarga karyawan tersebut. ${ }^{4}$ Masalah kompensasi merupakan fungsi manajemen personalia yang paling sulit dan membingungkan. Tidak hanya karena pemberian kompensasi merupakan salah satu tugas yang paling kompleks, tetapi juga merupakan salah satu aspek yang paling berarti baik bagi karyawan maupun organisasi. Bila perusahaan tidak memperhatikan kompensasi bagi karyawannya maka akan semakin besar kemungkinan bagi perusahaan untuk kehilangan sumber daya manusia yang berkualitas tinggi dan berperan dalam pencapaian tujuan perusahaan. Sari Sofa Lumajanag dalam memberikan kompensasi kepada para karyawan terlebih dahulu melakukan penghitungan kinerja dengan membuat sistem

4 Aityan, S. dan Gupta, T.K.P., 2011. Challenges of Employee Loyalty in Corporate America. Business and Economics Journal 
penilaian kinerja yang adil. Sistem tersebut umumnya berisi kriteria penilaian setiap pegawai yang ada misalnya mulai dari jumlah pekerjaan yang bisa diselesaikan, kecepatan kerja, komunikasi dengan karyawan lain, perilaku, pengetahuan atas pekerjaan, dan lain sebainya. Kompensasi yang selama ini terjadi di Sari Sofa Lumajang adalah dengan pemberian komisi kepada karyawan yang terlibat dalam penjualan, memberikan upah setiap bulan sesuai dengan hari kerja, memberikan uang tunai setiap hari raya, uang lembur diberikan setengah dari upah harian. Pemberian konpensasi yang layak kepada karyawan berdampak pada kinerjanya, dengan kompensasi yang layak maka karyawan akan semangat dalam bekerja sehingga memungkinkan pencapaian kienerja akan semakin baik.

\section{KAJIAN PUSTAKA}

\section{TINJAUAN PUSTAKA MOTIVASI}

Motivasi berasal dari kata latin Movere yang artinya dorongan atau mengarahkan. Motivasi ditunjukan pada sumber daya manusia umumnya dan bawahan khususnya. ${ }^{5}$ Motivasi mempersoalkan bagaimana caranya mengarahkan daya potensi bawahan, agar mau bekerja sama secara produktif, berhasil mencapai dan mewujudkan tujuan yang telah ditentukan. Motivasi yaitu kesediaan untuk mengeluarkan tingkat upaya yang tinggi untuk tujuan organisasi yang dikondisikan oleh kemampuan upaya itu untuk memenuhi beberapa kebutuhan individual. ${ }^{6}$ Motivasi juga diartikan sebagai hasrat yang terdapat di dalam diri seseorang yang menyebabkan orang tersebut melakukan

${ }^{5}$ Hasibuan, Malayu. 2012. Manajemen Sumber Daya manusia. (Jakarta: PT Bumi Aksara), hlm. 141.

6 Robbins, Stephen P. 2001. Perilaku Organisasi, Edisi 8. (Jakarta : Prentice Hall), hlm. 166 
tindakan. ${ }^{7}$

Motivasi adalah segala sesuatu yang menjadi pendorong tingkah laku yang menuntut atau mendorong orang untuk memenuhi suatu kebutuhan. ${ }^{8}$ Motivasi merupakan masalah yang komplek pada organisasi atau instansi, karena motivasi setiap karyawan atau sumber daya manusia berbeda satu sama lain. Manusia merupakan makhluk yang unik baik secara fisik maupun mental. Untuk itu seorang pimpinan harus mengetahui motivasi karyawannya, sebab faktor ini penting untuk mengoptimalkan kinerja sumber daya manusia, yang akhirnya untuk mencapai tujuan instansi. Motivasi adalah serangkaian sikap dan nilai yang mempengaruhi individu untuk mencapai hal yang spesifik sesuai dengan tujuan individu. ${ }^{9}$ Manusia dalam suatu kegiatan tertentu bukan saja berbeda dalam kemampuannya, namun juga berbeda dalam kemauan untuk menyelesaikan pekerjaan tersebut. Motivasi adalah dorongan atau semangat seseorang dalam melaksanakan pekerjaannya. ${ }^{10}$ Dengan kata lain setiap pekerja memerlukan motivasi yang kuat agar bersedia melaksanakan pekerjaan secara bersemangat, bergairah dan berdedikasi. Kenyataan menunjukkan pula bahwa kegiatan yang didorong oleh sesuatu yang tidak disukai berupa kegiatan yang terpaksa dilakukan, cenderung berlangsung tidak efektif dan tidak efisien.

\section{KOMPENSASI}

7 Mathis, Robert L., dan John Harold Jackson, 2013, Human Resources Management, Thomson Learning,hlm. 89

8 Siagian, Sondang,2007, Manajemen Sumber Daya Manusia, (Jakarta : PT. Bumi Aksara), hlm. 285

99 Rivai, Veithzal. 2009. Manajemen Sumber Daya Manusia Untuk Perusahaan : Dari Teori ke Praktik. Jakarta: Raja Grafindo Persada ,hlm. 837

${ }^{10}$ Hadari Nawawi, et.al. 2006. Kepemimpinan yang Efektif. (Yogyakarta : UGM Press),hlm. 351 
Kompensasi merupakan apa yang diterima oleh para karyawan sebagai ganti konstribusi mereka kepada organisasi. ${ }^{11}$ Kompensasi adalah salah satu cara organisasi untuk meningkatkan prestasi kerja, motivasi, dan kepuasan kerja pada karyawan. ${ }^{12}$ Kompensasi adalah keseluruhan balas jasa yang diterima oleh karyawan sebagai akibat pelaksanaan pekerjaan diorganisasi dalam bentuk uang atau lainnya, yaitu dapat berupa gaji, upah, bonus, insentif dan tunjangan lainnya seperti tunjangan kesehatan, tunjangan hari kerja, uang makan, uang cuti dan lain - lain. ${ }^{13}$ Kompensasi adalah semua pendapatan yang berbentuk uang, barang langsung atau tidak langsung yang diterima karyawan sebagai imbalan atas jasa yang diberikan kepada perusahaan. ${ }^{14}$

Kompensasi dapat dibedakan menjadi dua, yaitu; ${ }^{15}$

1. Kompensasi langsung (Financial) adalah kompensasi yang langsung dirasakan oleh penerimanya, yaitu berupa gaji, tunjangan, dan insentif merupakan hak karyawan dan kewajiban perusahaan untuk membayarnya.

2. Kompensasi tidak langsung (Non financial) adalah kompensasi yang tidak dapat dirasakan secara langsung oleh karyawan, yaitu benefit dan services (tunjangan pelayanan). Benefit dan services adalah kompensasi tambahan yang diberikan berdasarkan kebijakan perusahaan terhadap semua karyawan

11 Henry Simamora. 2004. Manajemen Sumber Daya Manusia. Edisi Ke-3. STIE YKPN, hlm. 442

12 Rachmawati, Ike Kusdyah. 2008. Manajemen Sumber Daya Manusia. (Yogyakarta : ANDI),hlm. 144

${ }^{13}$ Hariandja, Marihot Tua Efendi. 2007. Manajemen Sumber Daya Manusia : Pengadaan, Pengembangan, Pengkompensasian, dan Peningkatan Produktivitas Pegawai. (Jakarta : Grasindo) ,hlm. 224

${ }^{14}$ Ibid, hlm. 6

15 Sutrisno, Edi. 2009. Manajemen Sumber Daya Manusia Edisi pertama. (Jakarta: Kencana Prenada Media Group), hlm. 182 
dalam usaha meningkatkan kesejahteraan mereka. Seperti uang pensiun, olah raga dan darma wisata (family gathering).

\section{KINERJA}

Kinerja adalah perilaku nyata yang ditampilkan setiap orang sebagai prestasi kerja yang dihasilkan oleh karyawan sesuai dengan perannya dalam organisasi. ${ }^{16}$ Kinerja dapat diartikan sebagai prestasi atau kemampuan karyawan yang mencakup unsur-unsur keandalan, prakarsa, inovasi, ketelitian, hasil kerja, kehadiran, sikap, kerja sama, kerapian, mutu pekerjaan dan lain-lain. Kinerja (performance) menunjuk pada prestasi karyawan terhadap tugas yang diberikan. ${ }^{17}$ Seorang karyawan dikatakan memiliki kinerja baik manakala karyawan tersebut memiliki prestasi yang baik dalam pelaksanaan tugas yang diembannya. Dalam pengertian tersebut, nampak jelas bahwa kinerja berkaitan dengan pencapaian (achievement) suatu pelaksanaan tugas. Kinerja adalah hasil kerja yang dapat dicapai oleh karyawan atau sekelompok orang dalam suatu organisasi sesuai degan wewenang dan tanggung jawab masing-masing dalam rangka upaya mencapai tujuan organisasi bersangkutan secara legal, tidak melanggar hukum dan sesuai dengan moral etika. ${ }^{18}$

Kinerja dipengaruhi oleh faktor intrinsik yaitu personal individu dan faktor ekstrinsik yaitu kepemimpinan, sistem, tim, situasional, dan konflik. ${ }^{19}$

\section{${ }^{16}$ Ibid, hlm. 7}

17 Ibid, 7

18 Sedarmayanti. 2009. Sumber Daya Manusia dan Produktivitas Kerja. (Bandung: CV. Mandar Maju),hlm. 147

19 Mangkuprawira, Sjafri. 2007. Manajemen Mutu Sumber Daya Manusia. (Bogor:Ghalia Indonesia),hlm. 155 


\section{METODE PENELITIAN}

Penelitian ini dapat diklasifikasikan sebagai penelitian explanatory research yaitu penelitian yang mencoba menjelaskan suatu pokok permasalahan dan terdapat sebuah pengujian hipotesa serta melakukan analisis dari data yang diperoleh. Penelitian ini menggunakan Analisis Regresi Linier Berganda sebagai alat analisis data untuk menjelaskan pengaruh motivasi dan kompensasi kinerja karyawan di CV Sari Sofa Lumajang.

\section{HASIL DAN PEMBAHASAN}

\section{ANALISIS REGRESI LINIER BERGANDA}

Regresi berganda digunakan untuk mengetahui besarnya pengaruh variabel motivasi (X1), kompensasi (X2) terhadap kinerja (Y). Hasil pengujian regresi berganda dapat disajikan secara ringkas pada Tabel 1 :

Tabel 1. Hasil Analisis Regresi Linier Berganda

\begin{tabular}{lcl}
\hline \multicolumn{1}{c}{ Variabel Bebas } & Koefisien \\
\hline Regresi Motivasi & \multicolumn{2}{c}{0.360} \\
Kompensasi & 0.340 \\
\hline Variabel terikat $=$ Kinerja (Y) & Konstanta $=3.019$ \\
Fhitung $\quad=30.5432$ & R2 & $=0.761$ \\
R Adjust $\quad=0.701$ & & \\
\hline Sumber: Data diolah & &
\end{tabular}

Dari hasil analisis regresi linier berganda tersebut, dapat disusun dalam bentuk persamaan regresi sebagai berikut:

$$
\mathrm{Y}=3.019+0.360 \mathrm{X} 1+0.340 \mathrm{X} 2
$$

Persamaan regresi tersebut dapat dijelaskan bahwa kinerja karyawan bernilai positif yang berarti bahwa dengan tidak adanya variabel motivasi (X1), kompensasi (X2) maka kinerja (Y) karyawan tetap meningkat. Sementara variabel motivasi memberikan pengaruh yang positif terhadap 
kinerja. Hal ini berarti bahwa dengan motivasi karyawan yang tinggi maka kinerja juga akan semakin tinggi. Variabel berikutnya adalah kompensasi yang memberikan pengaruh positif terhadap kinerja, artinya apabila kompensasi yang diberikan oleh perusahaan semakin tinggi, maka kinerja karyawan juga akan semakin tinggi.

\section{PEMBAHASAN}

\section{Pengaruh Motivasi kerja Terhadap Kinerja}

Berdasarkan hasil penelitian diketahui bahwa motivasi kerja (X1) berpengaruh secara signifikan (nyata) terhadap Kinerja.Hasil penelitian ini sesuai dengan teori yang disampaikan Sudarwan yaitu motivasi kerja merupakan alasan-alasan, dorongan dorongan yang ada dalam diri manusia yang menyebabkan ia melakukan sesuatu atau berbuat sesuatu. ${ }^{20}$ Oleh sebab itu, dalam rangka upaya meningkatkan kinerja perusahaan maka intervensi terhadap motivasi sangat penting dan dianjurkan. Kinerja seorang tenaga kerja atau karyawan dipengaruhi oleh motivasi, kemampuan dan faktor persepsi. ${ }^{21}$

Adanya pengaruh motivasi terhadap kinerja berkaitan dengan indikator yang dijadikan pengukuran. Hasil penelitian menunjukkan bahwa rata-rata responden cukup setuju pada semua pernyataan mencapai $53.2 \%$, indikator yang memberikan sumbangan paling besar adalah pada pernyataan bekerja karena dijamin keselamatan atas kecelakaan kerja (72.1\%).

\section{Pengaruh Kompensasi terhadap Kinerja}

20 Sudarwan. 2004. Motivasi Kepemimpinan dan Efektivitas Kelompok. (Bengkulu: PT Rineka Cipta), hlm. 15

${ }^{21}$ Notoatmodjo, Soekidjo. 2009. Pengembangan Sumber Daya Manusia. Jakarta :Rineka Cipta, hlm 125 
Berdasarkan hasil penelitian diketahui bahwa kompensasi (X2) berpengaruh secara signifikan terhadap Kinerja. Hasil penelitian ini sesuai dengan teori yang disampaikan Mathis dan Jackson, (2000:113) salah satu cara manajemen untuk meningkatkan prestasi kerja, memotivasi dan meningkatkan kepuasan kerja para karyawan adalah melalui kompensasi. Secara sederhana kompensasi merupakan sesuatu yang diterima karyawan untuk balas jasa kerja mereka. ${ }^{22}$ Kompensasi dalam bentuk finansial adalah penting bagi karyawan, sebab dengan kompensasi ini mereka dapat memenuhi kebutuhannya secara langsung, terutama kebutuhan fisiologisnya. ${ }^{23}$ Namun demikian, tentunya karyawan juga berharap agar kompensasi yang diterimanya sesuai dengan pengorbanan yang telah diberikan dalam bentuk nonfinansial juga sangat penting bagi karyawan terutama untuk pengembangan karir mereka.

Adanya pengaruh kompensasi terhadap kinerja berkaitan dengan indikator yang dijadikan pengukuran. Hasil penelitian menunjukkan bahwa rata-rata responden cukup setuju pada semua pernyataan mencapai 54.7\%, indikator yang memberikan sumbangan paling besar adalah pada pernyataan mendapatkan fasilitas kendaraan dari perusahaan $(69.8 \%)$.

CV. Sari Sofa lumajang memberikan uang tambahan pada karyawan yang tugas tambahan atau pekerjaan diluar tugas rutinnya; Perusahaan juga memberikan THR kepada karyawan setiap hari besar seperti lebaran idul adha dan idul fitri; beberapa karyawan diberikan fasilitas kendaran yang digunakan untuk kegiatan kerja. Kompensasi memiliki arti penting bagi karyawan, karena dengan mendapatkan kompensasi maka karyawan akan terdorong atau memiliki semangat kerja yang tinggi. Sehingg akan mudah peruhaan 
dalam mencapai target apabila karyawan dalam bekerja maksimal.

\section{KESIMPULAN}

1. Motivasi kerja berpengaruh positif dan signifikan terhadap kinerja karyawan pada Perusahaan Meubel CV. Sari Sofa Lumajang. Hal ini memberikan pemahaman bahwa semakin tinggi motivasi kerja karyawan maka akan semakin meningkat kinerjanya sehingga tujuan perusahaam akan mudah dicapai.

2. Kompensasi berpengaruh positif dan signifikan terhadap kinerja karyawan pada Perusahaan Meubel CV. Sari Sofa Lumajang. Hal ini memberikan pemahaman bahwa dengan adanya kompensasi karyawan maka akan semakin meningkat kinerjanya sehingga tujuan perusahaam akan mudah dicapai.

\section{DAFTAR PUSTAKA}

Aityan, S. dan Gupta, T.K.P., 2011. Challenges of Employee Loyalty in Corporate America. Business and Economics Journal.

Alex, S., Nitisemito, 2001. Manajemen Personalia, Ghalia Indonesia, Jakarta.

Anas, Muhammad. 2010. Pengaruh Motivasi terhadap Kinerja Pegawai pada Kantor Balai Perbenihan Tanaman Hutan Sulawesi . Jurnal Motivasi terhadap Kinerja, h:117.

Ardana,

Komang

dkk.2009.

Perilaku

Keorganisasian.Yogyakarta: Graha Ilmu

Arikunto, S. 2011. Prosedur Penelitian Suatu Pendekatan Praktik. Jakarta: Rineka Cipta

Aulia. Alif Furqoni dan Eka Afnan Troena. 2013. Pengaruh Kompensasi Finansial dan Non Finansial Terhadap Motivasi Kerja Karyawan Universitas Brawijaya Hotel 
Kota Malang [Skripsi]. Universitas Brawijaya

Badriyah, M. 2015. Manajemen Sumber Daya Manusia, Cetakan 1. Bandung : CV Pustaka. Setia.

Daft, Richard L. 2003. Manajemen Sumber Daya Manusia. Jakarta: Penerbit Erlangga Danim,

Sudarwan. 2004. Motivasi Kepemimpinan dan Efektivitas Kelompok. Bengkulu: PT Rineka Cipta

Djati, S. Pantja dan M. Khusaini. 2003. Kajian terhadap kepuasan kompensasi, komitmen organisasi, dan prestasi kerja. Jurnal Manajemen dan Kewirausahaan, 5(1), 25-41

Ghozali, Imam, 2013. Aplikasi Analisis Multivariat dengan Program IBM SPSS 21. Edisi 7, Penerbit Universitas Diponegoro, Semarang.

Hadari Nawawi, et.al. 2006. Kepemimpinan yang Efektif. Yogyakarta : UGM Press.

Hariandja, Marihot Tua Efendi. 2007. Manajemen Sumber Daya Manusia : Pengadaan, Pengembangan, Pengkompensasian, dan Peningkatan Produktivitas Pegawai. Jakarta : Grasindo

Hasibuan, Malayu. 2012. Manajemen Sumber Daya manusia. Jakarta: PT Bumi Aksara.

Henry Simamora. 2004. Manajemen Sumber Daya Manusia. Edisi Ke-3. STIE YKPN.

Mangkunegara, Anwar Prabu . 2009. Manajemen Sumber Daya Manusia. Bandung: PT. Remaja Rosdakarya.

Mangkuprawira, Sjafri. 2007. Manajemen Mutu Sumber Daya Manusia. Bogor:Ghalia Indonesia

Mangkuprawira, Sjafri. 2007. Manajemen Mutu Sumber Daya Manusia. Bogor:Ghalia Indonesia

Mardiana, 2005, Manajemen Produksi, Penerbit Badan Penerbit IPWI, Jakarta. 
Mardiana, 2005, Manajemen Produksi, Penerbit Badan Penerbit IPWI, Jakarta.

Mathis, Robert L., dan John Harold Jackson, 2013, Human Resources Management, Thomson Learning.

Notoatmodjo, Soekidjo. 2009. Pengembangan Sumber Daya Manusia. Jakarta :Rineka Cipta

Rachmawati, Ike Kusdyah. 2008. Manajemen Sumber Daya Manusia. Yogyakarta : ANDI.

Rivai, Veithzal. 2009. Manajemen Sumber Daya Manusia Untuk Perusahaan : Dari Teori ke Praktik. Jakarta: Raja Grafindo Persada

Robbins, Stephen P. 2001. Perilaku Organisasi, Edisi 8. Jakarta : Prentice Hall

Sariyathi, Ni Ketut. 2007. "Prestasi Kerja Karyawan". Buletin studi ekonomi. Volume 12 Nomor

Sedarmayanti. 2009. Sumber Daya Manusia dan Produktivitas Kerja. Bandung: CV. Mandar Maju.

Siagian, Sondang,2007, Manajemen Sumber Daya Manusia, Jakarta : PT. Bumi Aksara

Subekhi, Akhmad, Mohammad Jauhar. 2012. Pengantar Manajemen Sumber Daya Manusia. Prestasi Pustaka Jakarta. Jakarta.

Sugiyono, 2008. Metode Penelitian Kunatitatif Kualitatif dan R\&D. Bandung : Alfabeta.

Sutrisno, Edi. 2009. Manajemen Sumber Daya Manusia Edisi pertama. Jakarta: Kencana Prenada Media Group. 
